\title{
ГЕОДЕЗІЯ
}

УДК 332.3.003.12

DOI https://doi.org/10.32838/2663-5941/2019.6-2/36

\section{Домашенко Г.T.}

Уманський національний університет садівництва

Міхно П.Б.

Кременчуцький національний університет імені Михайла Остроградського

Артамонов В.В.

Кременчуцький національний університет імені Михайла Остроградського

Рудоман Ю.А.

ДП «Кропивницький інститут землеустрою»

\section{ОСОБЛИВОСТІ ЗАСТОСУВАННЯ ЕКСПЕРТНИХ ОЦНОК ДЛЯ СТРАТЕГІЧНОЇ ЕКОЛОГІЧНОЇ ОЦІНКИ ГЕНЕРАЛЬНИХ ПЛАНІВ НАСЕЛЕНИХ ПУНКТІВ}

Стратегічна екологічна оиінка має виявити найоптимальніший сиенарій досягнення максимально можливого рівня збереження довкілля. Переваги стратегічної екологічної оцінки полягають у підвищенні якості розроблення стратегій, планів і програм, виявленні нових можсливостей розвитку та запобіганні збитків внаслідок усунення можсливої шкоди навколишньому середовищу ще на стадії планування.

Загальна проблема застосування стратегічної екологічної оцінки в Украӥні полягає у новизні иъього заходу, ще потребує врахування зарубіжного досвіду ї̈ виконання та належного методологічного забезпечення. Проблемою, яка потребує особливої уваги, є обтрунтування і вибір методів виконання стратегічної екологічної оцінки для конкретних видів проектної документаиї̈ та матеріалів стратегічного планування.

Новизною дослідження $є$ рекомендащії щодо порядку застосування експертних оцінок для розв'язання ключових завдань стратегічної екологічної оцінки генеральних планів населених пунктів. Визначено особливості такого застосування. Для встановлення рейтингу екологічних проблем планованої діяльності запропоновано застосовувати метод апріорного ранжування. Пропозиції реалізовані на прикладі генерального плану села Зелене Петрівського району Кіровоградської області. Проведено опитування експертів.

Складено матрищю рангів екологічних проблем. Розроблено апріорну діаграму рангів. Складено рейтинг екологічних проблем. Визначено найбільш важливі проблеми, яким потрібно приділити особливу увагу, і найменш важливі, якими можна знехтувати при подальшому аналізі та оцінці стану навколишнього середовища на території иього населеного пункту.

Ключові слова: стратегічна екологічна оцінка, апріорне ранжування, ранг, документ державного планування, генеральний план.

Постановка проблеми. У контексті стратегії сталого (збалансованого) розвитку суспільства та європейської інтеграції України одним із дієвих заходів запобігання погіршення поточного стану навколишнього середовища є оцінка документів щодо планування територіального розвитку держави з точки зору впливу на довкілля. Важливими аспектами такої оцінки є правові (обов'язки, відповідальність суб'єктів оцінки), екологічні (відповідність результатів оцінки реальному стану об'єкта, реалістичність прогнозів щодо покращення стану довкілля) та соціально-економічні (отримання певного позитивного економічного ефекту від вибору найбільш раціональних варіантів розвитку та переваг для соціальної сфери із дотриманням екологічних вимог і обмежень на провадження господарської діяльності). 
У практиці багатьох країн застосовуються оцінка впливу на навколишнє середовище (ОВНС) та стратегічна екологічна оцінка (CEO). Законом України «Про охорону навколишнього природного середовища» $[1$, с. 206] регламентовано необхідність виконання екологічної експертизи проектів, програм, планів і техніко-економічних обгрунтувань розвитку.

Для вдосконалення механізму оцінки можливого впливу на довкілля від реалізації проектів та програм останнім часом прийнято та уведено у дію нові Закони України $[2 ; 3]$ та методичні рекомендації щодо практичної реалізації їх положень [4]. Закон України «Про оцінку впливів на довкілля» [3] встановлює правові та організаційні засади оцінки впливу на довкілля, спрямованої на запобігання нанесення шкоди довкіллю, забезпечення екологічної безпеки, охорони довкілля, раціонального використання і відтворення природних ресурсів, у процесі прийняття рішень щодо провадження господарської діяльності. Закон «Про стратегічну екологічну оцінку» [2] визначає підстави, об'єкти, повноваження суб'єктів господарювання та особливості СЕО матеріалів державного планування.

Актуальність дослідження визначається інтеграцією України у простір Європейського Союзу, що потребує, зокрема, адаптації вітчизняного державного територіального планування до європейських концепцій за переваги екологічного імперативу. СЕО обов'язкова для виконання всіма країнами - членами $Є С$.

Завдання дослідження пов'язані із реалізацією положень міжнародних та вітчизняних концепцій щодо виконання екологічної оцінки документів державного планування, таких як: Директива 2001/42/СС, Конвенція про оцінку впливу на навколишнє середовище у транскордонному контексті.

Аналіз останніх досліджень i публікацій. Методологічні засади застосування СЕО пропонованих стратегій, планів і програм в різних галузях в Україні і світі досліджують Г.Б. Марушевський, М.В. Хотулєва, А.В. Чернишевська, І.В. Шевченко, В. Sadler та інші. Водночас, недостатньо дослідженою залишається проблема методичного забезпечення практичного впровадження СЕО.

Наукові дослідження у цій сфері [5; 6, с. 82] пропонують різні підходи до виконання СЕО різних документів державного планування. Спільною їх ознакою $є$ бажаність та доцільність залучення у якості експертів фахівців зі споріднених галузей - екології, землеустрою, містобудування, охорони праці, охорони здоров'я для оцінки альтернативних варіантів територіального розвитку 3 точки зору впливу на довкілля. Залучення зацікавлених спеціалістів до обговорення проблем i перспектив матиме довгостроковий позитивний наслідок через підвищення суспільної обізнаності та краще висвітлення проблем території [5-8].

Наказ Міністерства екології та природних ресурсів України від 10.08.2018 № 296 [4] визначає загальний перелік підходів, методів та способів, які можна застосовувати для розв'язання завдань СЕО, проте без конкретизації у розрізі землевпорядної, містобудівної документації та матеріалів стратегічного планування.

Формулювання цілей статті. Незважаючи на значну теоретичну вивченість проблеми, потребують подальшої наукової розробки питання, пов'язані зі стратегічною екологічною оцінкою містобудівної документації. Завданням дослідження $\epsilon$ обгрунтування застосування методу апріорного ранжування для стратегічної екологічної оцінки генеральних планів населених пунктів.

Методологічне або загальнонаукове значення полягає у застосуванні механізму зменшення ваги суб'єктивної складової у експертних судженнях під час виконання стратегічної екологічної оцінки. Розвинуто існуючі рекомендації [4] у розрізі покращення виконання стратегічної екологічної оцінки генеральних планів сіл та селищ.

Виклад основного матеріалу дослідження. Стратегічна екологічна оцінка - це процес виявлення та врахування факторів впливу та можливих наслідків від реалізації стратегій, планів, програм, що розробляються та впроваджуються [5].

СЕО підлягають $[2 ; 8$, с. 3] прогнози та програми економічного та соціального розвитку України, АР Крим, областей, районів, міст, прогнозів розвитку галузей економіки, містобудівна документація [9] та схеми землеустрою, виконання яких передбачає реалізацію діяльності, що потребує [3] оцінки впливів на довкілля. Тому стратегічній екологічній оцінці підлягають очікувані для довкілля наслідки виконання документів державного планування, можливі альтернативи.

СЕО здійснюється у процесі розроблення документа державного планування за принципами наукової обгрунтованості, законності, об'єктивності, участі громадськості, збалансованості інтересів, комплексності, запобігання екологічній шкоді, достовірності.

У процесі стратегічної екологічної оцінки документа державного планування розв'язують такі основні завдання [2; 5; 7, с. 54]: аналіз цілей; 
аналіз поточного стану довкілля і трендів розвитку; аналіз стану довкілля на територіях, які ймовірно зазнають впливу; визначення екологічних проблем; аналіз потенційно можливих наслідків для довкілля; визначення заходів для запобігання, зменшення, пом'якшення негативних наслідків; вибір виправданих альтернатив; обгрунтування заходів моніторингу довкілля; аналіз ймовірних транскордонних наслідків.

Інструментами СЕО рекомендується [4; 5] застосовувати матриці, ГІС-моделі, експертні оцінки. Вихідними даними для виконання оцінки, $€$ : доповіді про стан довкілля, статистичні збірники, екологічні паспорти, нормативні та законодавчі акти, що мають відношення до документів державного планування, дані моніторингу довкілля, експертні оцінки.

Експертні оцінки можна отримати шляхом кількісного вираження вербальних експертних суджень членів робочої групи з виконання стратегічної екологічної оцінки. Експерти повинні бути ознайомлені із досліджуваною проблемою, приймати участь у іiі розв'язанні, мати однаковий або співставлений рівень компетентності і не бути особисто зацікавленими в будь-якому варіанті.

Експерти формують свої судження на підставі практичного досвіду, проведеного теоретичного аналізу, знайомства 3 аналогічними розробками закордонних авторів та власної інтуїції. Експертні оцінки можна застосовувати для встановлення рейтингу екологічних проблем об'єкта провадження планованої діяльності,аналізу альтернатив, визначення відповідності екологічних цілей документа державного планування стратегічним екологічним цілям регіональних програм розвитку.

При цьому найбільш важливими 3 точки зору стратегічної екологічної оцінки $є$ аналіз альтернативних рішень документа державного планування для знаходження можливостей зменшення негативного впливу на довкілля і аналіз екологічної ситуації на території місцезнаходження об'єкта планованої діяльності для складання рейтингу екологічних проблем. Адже правильно оцінений ступінь важливості екологічних проблем певним чином дозволяє визначати шляхи їх усунення або зменшення, та загальну ефективність природоохоронних заходів.

Авторами пропонується наступний порядок роботи робочої групи з розроблення СЕО. Звіт складається інженером-землевпорядником, який розв'язує більшість завдань СЕО самостійно, але iз урахуванням порад від членів робочої групи на підставі отриманої від них додаткової інформації. При цьому встановлення альтернатив здійснюється колегіальним обговоренням, а рейтинг екологічних проблем встановлюється шляхом обробки експертних оцінок, отриманих в результаті незалежного анкетування експертів.

Для встановлення відповідності екологічних цілей документа державного планування стратегічним екологічним цілям діючих регіональних програм розвитку доцільно застосувати їх нечітку оцінку за методом нечітких множин для більш адекватного відображення різних ступенів неповної відповідності.

Щодо встановлення рейтингу екологічних проблем, то найпростішим варіантом є їх розташування в порядку зменшення соціальної та екологічної значущості. Недоліком такого підходу $є$ складність правильного встановлення рейтингу взаємозалежних екологічних проблем або таких, що $є$ наслідками інших. Можна припустити, що подібні проблеми повинні мати однакову вагу у ряді проблем. Тому доцільним $є$ застосування апріорного ранжування, яке дозволяє надавати однаковий ранг проблемам рівної важливості. За допомогою ранжування екологічні проблеми розміщуються в порядку спадання їх впливу на стан довкілля (зменшення важливості, пріоритетності або першочерговості).

У наукових дослідженнях обгрунтовано засоби, які надають надійні результати оцінки узгодженості експертних суджень різних експертів $[10$, c. $32 ; 11$, c. 143$]$. Такими засобами, зокрема, $\epsilon$ коефіцієнт конкордації та критерій Пірсона. Відповідне експертне опитування щодо екологічних проблем доцільно здійснювати у два етапи. На першому експерти незалежно один від одного формують перелік екологічних проблем планованої діяльності (або об'єкта планованої діяльності). Шляхом об'єднання переліків кожного експерта формується загальний перелік, що містить усі екологічні проблеми. На другому етапі екологічні проблеми ранжуються.

Одним із проблемних питань експертного опитування $€$ встановлення мінімально необхідної (достатньої) кількості експертів та їх якісного складу. Зрозуміло, що при збільшенні кількості експертів вплив судження кожного окремого експерта на ваги оцінюваних параметрів зменшується i результати можуть бути більш достовірними. Хоча це не відміняє цілком можливої ситуації, за якої можуть помилятися, або мати суперечливі судження усі залучені до аналізу експерти, що 3 різних причин мислять однаково. 
Тому головним критерієм має бути не велика, статистично обгрунтована, кількість експертів, а забезпечення їх бажаного якісного складу. Переважно, це стосується глибини та рівня знань щодо досліджуваної проблеми, що визначається досвідом практичної та теоретичної роботи. При цьому необхідно охопити усі аспекти досліджуваної проблеми. Тому до складу експертної групи доцільно включити фахівців, що мають досвід участі у розробці подібної документації з державного планування та звітів з їх стратегічної екологічної оцінки, а саме: інженера-землевпорядника, інженера-еколога, інженера з охорони праці, спеціаліста у сфері контролю за санітарно-епідеміологічним станом довкілля та охорони здоров'я населення, науковця, представника громадської екологічної організації, представника територіальної громади (жителя населеного пункту у зоні впливу об'єкта планованої діяльності), а також посадових осіб органу місцевого самоврядування (сільської, міської, районної або обласної ради), місцевої державної адміністрації та територіального органу Держгеокадастру, які мають пряме відношення до планованої діяльності.
Пропонований алгоритм застосування експертних оцінок для СЕО документів державного планування наведено на рис. 1.

Коефіцієнт конкордації визначається за формулою [11, с. 143]:

$$
\mathrm{W}=\frac{12 \cdot \sum_{i=1}^{n}\left(\Delta i_{i}\right)^{2}}{l^{2} \cdot\left(n^{3}-n\right)-l \sum_{j=1}^{l}\left(\sum_{p=1}^{z}\left(t_{j p}^{3}-t_{j p}\right)\right)},
$$$$
\text { де: } \Delta i_{\mathrm{i}}=\sum_{j=1}^{l} c_{i j}-\frac{\sum_{i=1}^{n}\left(\sum_{j=1}^{l} c_{i j}\right)}{n} \text {; }
$$

$l$ - кількість експертів у анкетуванні; $n$ - кількість ранжованих величин; $\mathrm{z}$ - кількість груп 3 однаковими рангами у $j$-того експерта; $t_{j p}-$ кількість факторів у групі $p ; c_{i j}-$ ранг $i$-го фактора у $j$-го експерта.

Значущість коефіцієнта конкордації перевіряють критерієм Пірсона:

$$
\chi^{2}=\frac{12 \cdot \sum_{i=1}^{n}\left(\Delta i_{i}\right)^{2}}{l \cdot n \cdot(n+1)-\frac{1}{n-1} \sum_{j=1}^{l}\left(\sum_{p=1}^{z}\left(t_{j p}^{3}-t_{j p}\right)\right)} .
$$

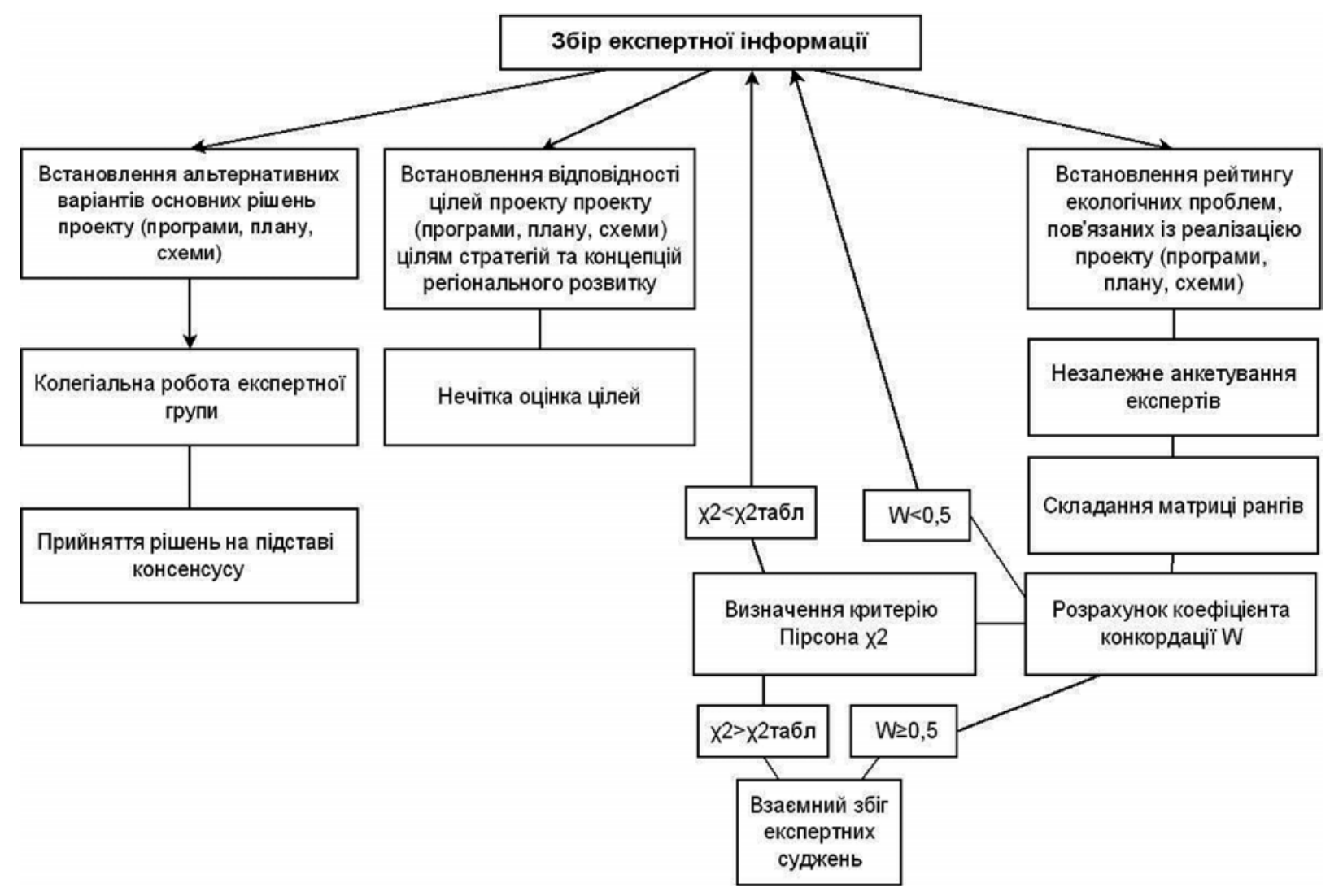

Рис. 1. Алгоритм застосування експертних оцінок для стратегічної екологічної оцінки документів державного планування 
Групою 310 експертів встановлено перелік екологічних проблем села Зелене Петрівського району Кіровоградської області (генплан цього села і звіт $з$ його стратегічної екологічної оцінки знаходяться у стадії розробки):

I. Наявність підприємства з виробництва пілетів з відходів сільськогосподарської продукції;

II. Забруднення повітря продуктами горіння через виробництво пілетів;

III.Знаходження південної частини села (за нормами ДСП 173-96. Держані санітарні правила планування і забудови населених пунктів) у межах санітарно-захисної зони кар’єру № 4 Центрального гірничозбагачувального комбінату (ЦГЗК);

IV. Періодичне акустичне забруднення повітря внаслідок видобування залізної руди на кар'єрі № 4 ЦГЗК;

V. Періодичне забруднення повітря пилом внаслідок видобування залізної руди на кар’єрі № 4 ЦГЗК;

VI. Відсутність або незадовільний стан каналізаційних мереж;

VII. Обмеженість джерел водопостачання;

VIII.Недостатня розвиненість системи екологічного моніторингу;

IX. Низький рівень використання відновлювальних джерел енергії;

$\mathrm{X}$. Низький рівень впровадження енергоощадних технологій при будівництві будівель і споруд;
XI. Низький рівень екологічної культури у населення.

XII. Замулення русел річок в межах села та необхідність їх розчищення.

У табл. 1 наведено приклад апріорного ранжування екологічних проблем села Зелене.

Експерти встановили ранги проблем (табл. 1), користуючись власним практичним досвідом та статистичними даними 3 відкритих джерел [12-14].

Табличне значення критерію Пірсона менше розрахункового, а коефіцієнт конкордації значно відрізняється від нулю та наближається до одиниці, тому можна стверджувати про достатню узгодженість експертних суджень (3 довірчою ймовірністю 95\%). Апріорна діаграма рангів наведена на рис. 2.

Чим менша сума рангів (рис. 2), тим більший вплив ця проблема здійснює на стан навколишнього середовища.

Найважливішими проблемами на території с.Зелене є виробництво пілетів, забруднення повітря, безпосередня близькість до залізорудного кар'єру. Убування немонотонне і нерівномірне (рис. 2). Тому відкинути за результатами попереднього аналізу можна найменш впливові проблеми для довкілля: низький рівень використання відновлювальних джерел енергії, впровадження

Таблиця 1

Матриця рангів екологічних проблем с. Зелене

\begin{tabular}{|c|c|c|c|c|c|c|c|c|c|c|c|c|}
\hline \multirow{2}{*}{ Експерт } & \multicolumn{12}{|c|}{ Ранги порівнюваних проблем } \\
\hline & I & II & III & IV & $\mathbf{V}$ & VI & \begin{tabular}{|l|} 
VII \\
\end{tabular} & VIII & IX & $\mathbf{X}$ & XI & XII \\
\hline 1 & 1,5 & 1,5 & 4 & 4 & 4 & 7 & 7 & 9 & 10,5 & 10,5 & 12 & 7 \\
\hline 2 & 4 & 5 & 1 & 2,5 & 2,5 & 9 & 7 & 6 & 11 & 11 & 11 & 8 \\
\hline 3 & 1 & 2 & 3 & 4,5 & 4,5 & 7,5 & 7,5 & 9,5 & 11,5 & 11,5 & 9,5 & 6 \\
\hline 4 & 2 & 1 & 5 & 3,5 & 3,5 & 8 & 7 & 9 & 11 & 10 & 12 & 6 \\
\hline 5 & 1 & 3 & 2 & 4 & 5 & 7 & 6 & 11 & 9,5 & 9,5 & 12 & 8 \\
\hline 6 & 1,5 & 1,5 & 3 & 4,5 & 4,5 & 7,5 & 7,5 & 11 & 9,5 & 9,5 & 12 & 6 \\
\hline 7 & 2 & 1 & 5 & 4 & 3 & 7,5 & 7,5 & 7,5 & 11 & 11 & 11 & 7,5 \\
\hline 8 & 1 & 2 & 3 & 4 & 5 & 7,5 & 7,5 & 10 & 11,5 & 11,5 & 7,5 & 7,5 \\
\hline 9 & 1,5 & 1,5 & 4 & 4 & 4 & 7,5 & 7,5 & 7,5 & 10 & 11 & 12 & 7,5 \\
\hline 10 & 1 & 2 & 3 & 4 & 5 & 7 & 8 & 9 & 11 & 10 & 12 & 6 \\
\hline$\sum_{j=1}^{l} c_{i j}$ & 16,5 & 20,5 & 33 & 39 & 41 & 75,5 & 72,5 & 89,5 & 106,5 & 105,5 & 111 & 69,5 \\
\hline$\chi_{i}$ & $-48,5$ & $-44,5$ & -32 & -26 & -24 & 10,5 & 7,5 & 24,5 & 41,5 & 40,5 & 46 & 4,5 \\
\hline$\varnothing_{i}^{2}$ & 2352,25 & 1980,25 & 1024 & 676 & 576 & 110,25 & 56,25 & 600,25 & 1722,25 & 1640,25 & 2116 & 20,25 \\
\hline \multicolumn{2}{|c|}{$\sum_{i=1}^{n}\left(\Delta_{i}^{2}\right)=12874$} & \multicolumn{2}{|c|}{$\sum_{i=1}^{n}\left(\sum_{j=1}^{l} c_{i j}\right)=780$} & \multicolumn{2}{|c|}{$\frac{\sum_{i=1}^{n}\left(\sum_{j=1}^{l} c_{i j}\right)}{n}=65$} & \multicolumn{3}{|c|}{$\sum_{j=1}^{l}\left(\sum_{p=1}^{z}\left(t_{j p}^{3}-t_{j p}\right)\right.$} & \multicolumn{4}{|c|}{$\begin{array}{c}\mathrm{W}=0,92 ; \chi^{2}=101,4 ; \chi_{\text {табл }}^{2}=19,68 \\
\text { для кількості ступенів свободи } \\
f=12-1=11 \text { і рівня значущості } 5 \% .\end{array}$} \\
\hline
\end{tabular}


енергоощадних технологій при будівництві, низький рівень екологічної культури.

Висновки. Розвинуто методичні підходи до виконання експертного оцінювання проблем територіального розвитку. Досліджено особливості застосування апріорного ранжування під час CEO генеральних планів населених пунктів. Запропоновано алгоритм розв'язання тих завдань стратегічної екологічної оцінки, які потребують застосування порівняльного аналізу досліджуваних проблем та цілей за ступенем вагомості. За допомогою апріорного ранжуванння встановлено рейтинг екологічних проблем села Зелене.

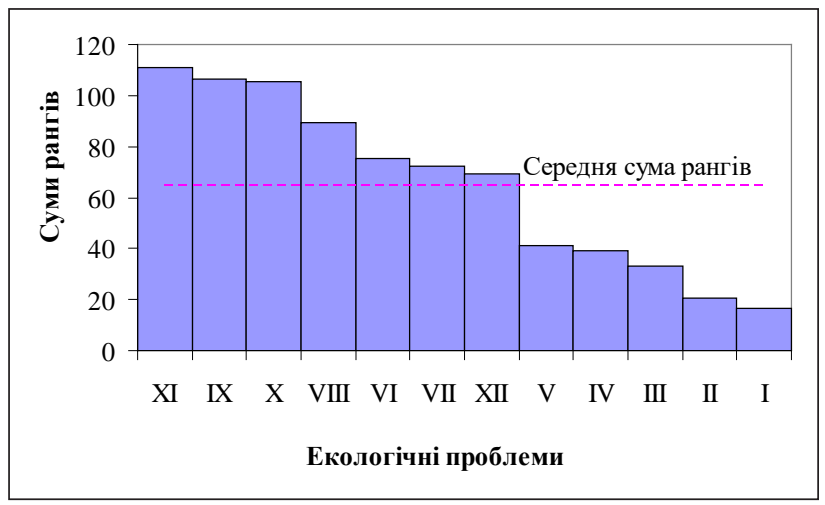

Рис. 2. Апріорна діаграма рангів

\section{Список літератури:}

1. Лісовий кодекс України. Кодекс України про надра. Водний кодекс України. Закон України «Про охорону навколишнього природного середовища». К. : Юрінком Інтер, 2006. 272 с.

2. Про стратегічну екологічну оцінку: Закон України від 20.03.2018 № 2354-VIII. URL: https://zakon.rada.gov.ua/laws/show/2354-19.

3. Про оцінку впливів на довкілля: Закон України від 23.05.2017 № 2059-VIII. URL: https://zakon.rada.gov.ua/laws/show/2059-19.

4. Про затвердження Методичних рекомендацій із здійснення стратегічної екологічної оцінки документів державного планування: Наказ Міністерства екології та природних ресурсів України від 10.08 .2018 № 296. URL: https://menr.gov.ua/files/docs/nakazy/2018/nakaz_296.pdf.

5. Sadler B. Environmental Assessment In A Changing World: Evaluating Practice to Improve Performance. International Study of the Effectiveness of Environmental Assessment. Ottawa: Canadian Environmental Assessment Agency and International Association for Impact Assessment, 1996. 420 p.

6. Шевченко I.В. Стратегічна екологічна оцінка як інструмент екологічної політики України. Економіка України. 2016. № 10. С. 79-86.

7. Марушевський Г. Стратегічна екологічна оцінка стратегії регіонального розвитку (на прикладі Дніпропетровської області). Державне управління та місцеве самоврядування. 2014. Вип. 4. С. 51-61.

8. Чернихівська А.В. Стратегічна екологічна оцінка регіонального розвитку: нормативно-правові та організаційно-управлінські аспекти впровадження. Ефективна економіка. 2010. № 10. URL: http://www.economy.nayka.-com.ua/?op=1\&z=357.

9. ДБН Б.2.2-12:2019. Планування та забудова територій. К., 2019. URL: http://dreamdim.ua/wp-content/ uploads/2019/07/DBN-B22-12-2019.pdf.

10. Вагонова О.Г., Романюк Н.М. Експертна оцінка напрямів розвитку гірничо-збагачувальних комбінатів. Економічний вісник. 2013. № 4. С. 29-35.

11. Бакуменко Л.П. Методика априорного ранжирования факторов качества жизни населения. Экономика, статистика и информатика. 2010. № 6. С. 142-149.

12. Екологічний паспорт Кіровоградської області за 2017 рік. 2018. 120 c. URL: https://menr.gov.ua/ news/32629.html.

13. Стратегія розвитку Кіровоградської області на період до 2020 року. 82 с. URL: http://economika. kr-admin.gov.ua/files/strategy_2020.pdf.

14. Регіональна доповідь про стан навколишнього природного середовища Кіровоградської області у 2016 році. 179 с. URL: https://menr.gov.ua/news-/31778.html.

\section{Domashenko H.T., Mikhno P.B., Artamonov V.V., Rudoman Yu.A. FEATURES OF THE USE OF EXPERT ASSESSMENTS FOR STRATEGIC ENVIRONMENTAL ASSESSMENT OF GENERAL PLANS FOR SETTLEMENTS}

The strategic environmental assessment should discover the most optimal scenario for achievement of the highest possible level of environmental protection. Advantages of a strategic environmental assessment are to improve the quality of working out of strategies, plans and programs, discovering of new opportunities for development and prevention of losses as a result of eliminating potential environmental damage at the planning stage. The general problem of application of a strategic environmental assessment in Ukraine is the novelty of this measure, that demands the consideration of foreign experience in its realization and proper methodological 
support. A problem that needs special attention is the justification and a choice of methods for performing of a strategic environmental assessment for concrete types of project documentation and strategic planning materials. The novelty of the research are recommendations on order of application of expert assessments for the decision of key tasks of a strategic environmental assessment of general plans of settlements.

Features of such application are defined. It is suggested to apply a priori ranging method to an establishment of a rating of environmental problems of the planned activity. The proposals are implemented on an example of the general plan of Zelene village, Petrovsky district of the Kirovograd region. Experts surveyed. The matrix of ranks of environmental problems is made. A priori ranks chart is developed.

The rating of environmental problems is made. The most important problems, which need to be given special attention, and the least important ones, which can be neglected at the further analysis and assessment of the environment in this settlement, are defined.

Key words: strategic environmental assessment, priori ranging, rank, state planning document, general plan. 